CLINICAL STUDY

\title{
Pituitary adenomas in childhood, adolescence and young adulthood: presentation, management, endocrine and metabolic outcomes
}

\author{
Caroline A Steele, Ian A MacFarlane, Joanne Blair ${ }^{1}$, Daniel J Cuthbertson, Mohammed Didi ${ }^{1}$, Conor Mallucci ${ }^{2}$, \\ Mohsen Javadpour ${ }^{2}$ and Christina Daousi \\ Diabetes and Endocrinology Clinical Research Group, Department of Endocrinology and Diabetes, Clinical Sciences Centre, Aintree University Hospitals \\ NHS Foundation Trust, Lower Lane, Liverpool L9 7AL, UK, ${ }^{1}$ Department of Paediatric Endocrinology, Alder Hey Children's NHS Foundation Trust, \\ Liverpool L12 2AP, UK and ${ }^{2}$ Department of Neurosurgery, The Walton Centre for Neurology and Neurosurgery, Liverpool L9 7LJ, UK \\ (Correspondence should be addressed to C A Steele; Email: c.a.steele@liverpool.ac.uk)
}

\begin{abstract}
Objective: To elucidate the long-term outcomes of pituitary adenomas diagnosed in childhood and adolescence, knowledge of which remains sparse.

Design and methods: A retrospective review of patients aged $\leq 21$ years at diagnosis of pituitary adenoma, attending a neuroendocrine service in Liverpool, UK, between 1984-2009.

Results: There were 41 patients (33 female), mean age at diagnosis 17.3 years (range 11-21) and mean follow-up 9.6 years; 29 patients had prolactinomas (15 macroprolactinomas), 6 non-functioning pituitary adenomas (NFPAs), 5 Cushing's disease (CD) and 1 acromegaly. All prolactinoma patients received dopamine agonists (DAs) and three also underwent pituitary surgery. Furthermore, ten patients underwent surgery: five with $\mathrm{CD}$, one with acromegaly and four with NFPA. Four received radiotherapy after surgery. Another ten patients received hormone replacement: nine hydrocortisone, five thyroxine, seven sex steroids and five GH; another seven had severe asymptomatic GH deficiency. Three female patients were treated for infertility (two successfully). Thirteen patients gained significant weight (body mass index (BMI) increase $>2 \mathrm{~kg} / \mathrm{m}^{2}$ ) since diagnosis and 16 in total are now obese $\left(\mathrm{BMI}>30 \mathrm{~kg} / \mathrm{m}^{2}\right)$. Five were treated with orlistat and one attended a weight management service. Two received antihypertensive medications, two had type 2 diabetes and four were treated for dyslipidaemia.

Conclusions: This is one of the largest reviews of patients aged 21 or younger at diagnosis of pituitary adenoma followed up by a single service. Two-thirds had prolactinomas, all were treated with DAs and three underwent surgery. Increased cardiovascular risk factors (obesity and dyslipidaemia) and infertility are important sequelae and active identification and treatment are necessary.
\end{abstract}

European Journal of Endocrinology 163 515-522

\section{Introduction}

Pituitary adenomas are uncommon in childhood and adolescence, accounting for $<3 \%$ of childhood supratentorial tumours (1) and between 3 and $6 \%$ of all surgically treated adenomas (2). Previous studies have typically been small $(\leq 21$ cases $(2-5))$, with the exception of a few larger studies with 26-44 patients (6-9), which often comprised of patients from multiple centres. The two largest studies (containing 136 (10) and 150 (11) patients) have described children with adenomas who have undergone surgery and represent a different patient group. Additionally, the definition of adolescence is variable between studies, with the upper limit for age ranging from 17 to 20 years. Owing to the ambiguity in defining adolescence and the fact that symptoms related to pituitary adenomas have been reported to begin $2-5$ years before diagnosis $(6,12,13)$, we retrospectively reviewed the hospital records of patients who were diagnosed with a pituitary adenoma up until the age of 21.

Previous studies have tended to report either the clinical features at presentation $(2,8,11)$ or the results of surgery $(3,10,14)$ with outcomes described in terms of visual field deficits, normalisation of hormones (in secreting tumours), loss of pituitary hormone function, remission/cure or the need for further treatment (radiotherapy or repeat surgery) for residual tumour $(6,7)$. In addition to these factors, we were also interested in investigating long-term sequelae, such as impaired fertility, which has been described in both adult patients with pituitary adenomas (15) and in those with hypopituitarism from various causes (e.g. adenomas, craniopharyngiomas, and Rathke's cleft 
cysts) (16), as well as in female survivors of childhood cancer who had received $\geq 30$ Gy dose of radiation to the hypothalamic/pituitary axis (17).

A worrying trend towards premature mortality has been reported in patients with hypopituitarism, secondary to increased cardiovascular and cerebrovascular events. One study found the largest increases in mortality in females, patients diagnosed at a young age and those treated with radiotherapy (18). In addition, many adults with hypopituitarism have multiple cardiovascular risk factors such as obesity, dyslipidaemia and hypertension $(19,20)$.

The aims of our study were dual: i) to describe the presentation, management and subsequent treatment outcomes of children and adolescents diagnosed with a pituitary adenoma in a joint neuroendocrine setting and followed up by a single service and ii) to assess longterm outcomes in terms of endocrine status (including fertility) and cardiovascular risk.

\section{Subjects and methods}

\section{Subjects}

The hospital records of patients aged $\leq 21$ years at diagnosis of pituitary adenoma were retrospectively reviewed. All had attended either the paediatric endocrine clinic at the local tertiary children's hospital (Alder Hey Children's Hospital) with subsequent referral on to the adult clinic or the joint neuroendocrine clinic run at University Hospital Aintree and the Walton Centre for Neurology and Neurosurgery (all in Liverpool, UK), with care provided as a single continuous service, between 1984 and 2009.

\section{Methods}

Clinical history, including presenting features, physical examination, auxology, body mass index (BMI) and baseline hormone results, were obtained where available. Mode of treatment was also assessed and classified as either medical, surgical or both. Ongoing endocrine problems, such as weight gain, GH deficiency (GHD), panhypopituitarism and infertility, were reviewed, along with current medical and drug histories.

Severe GHD in childhood was defined as peak GH $<5 \mu \mathrm{g} / \mathrm{l}$ on two separate tests (either glucagon stimulation test, insulin tolerance test or arginine test) in patients aged 16 or under, who were still growing. Severe adult-onset GHD was diagnosed in patients aged 17 or over, who had completed growth, with a peak GH $<3 \mu \mathrm{g} / \mathrm{l}$ on glucagon stimulation test. Visual fields were assessed in a single, dedicated neuro-ophthalmology unit using Goldmann perimetry, a manual kinetic visual field test.

\section{Statistical analysis}

Comparisons between groups were made with Student's $t$-test or with Mann-Whitney's $U$ test where appropriate. Data were analysed using SPSS version 15.0 (SPSS Inc., Chicago, IL, USA).

\section{Results}

There were 41 patients (33 female). Mean age at diagnosis was 17.3 years (median 17, range 11-21) and mean current age 26.9 years (median 26, range 15-46). Mean follow-up was 9.6 years (range 0.1-26). All patients had symptoms at presentation, with no adenomas being discovered co-incidentally (Table 1). Two patients had MEN1 syndrome (one diagnosed clinically with a prolactinoma and hyperparathyroidism and a family history of MEN1; the other patient with a prolactinoma was diagnosed on genetic testing and also had a family history of MEN1; the first patient had surgery for hyperparathyroidism, a jejunal leiomyoma, a gastrinoma and a pancreatic lesion and the other has a pancreatic body tumour and mild

Table 1 Symptoms and signs of patients at presentation; overall and by tumour type.

\begin{tabular}{lccccc}
\hline & Total & Prolactinoma & $\begin{array}{c}\text { ACTH-secreting } \\
\text { adenomas }\end{array}$ & $\begin{array}{c}\text { GH-secreting } \\
\text { adenomas }\end{array}$ & NFPA \\
\hline Number of patients & 41 & 29 & 5 & 1 & 6 \\
Gender (female/male) & $33 / 8$ & $28 / 1$ & $1 / 4$ & $0 / 1$ & $4 / 2$ \\
Symptoms and signs at presentation & & & & & \\
$\quad$ Primary amenorrhoea & 7 & 6 & 1 & 0 & 0 \\
Secondary amenorrhoea & 17 & 16 & 0 & 0 & 1 \\
Oligomenorrhoea & 4 & 3 & 0 & 0 & 1 \\
Galactorrhoea & 14 & 13 & 0 & 0 & 2 \\
Weight gain & 14 & 7 & 5 & 0 & 2 \\
Short stature & 4 & 1 & 1 & 1 & 0 \\
Tall stature & 1 & 0 & 0 & 0 & 4 \\
Headache & 11 & 5 & 2 & 1 & 2 \\
Visual field defects & 6 & 3 & 0 & 1 & 1 \\
Apoplexy & 3 & 1 & 0 & & 0 \\
\hline
\end{tabular}

NFPA, non-functioning pituitary adenoma. 
hyperparathyroidism). None of the other patients in our cohort had any known family history of pituitary disorders.

\section{Prolactinomas $(\mathbf{n}=29)$}

Of the 29 patients with prolactinoma (Table 2), only 1 was male. Their mean age at diagnosis was 18 years with mean prolactin at diagnosis $10238 \mathrm{mU} / \mathrm{l}$ (median $4220 \mathrm{mU} / \mathrm{l}$ ) and mean prolactin on dopamine agonists (DAs) $1073 \mathrm{mU} / \mathrm{l}$. The one male patient presented with pituitary apoplexy, with symptoms of headache, left hemianopia and right 3rd cranial nerve palsy. Only one patient presented with short stature (height SDS -2.4). Review of the available imaging at the time of presentation of the 15 patients with macroprolactinomas revealed that in only 3 patients the tumour was impinging on the optic chiasm and all 3 had visual field deficits detected by Goldmann perimetry. In the other cases there was no radiological evidence of anatomical proximity of the tumour to the optic chiasm to cause concerns over threat to vision.

All patients received DAs: ten bromocriptine only, eight cabergoline only, ten patients had been treated with both and one patient had been treated with quinagolide. Nine were switched to cabergoline from bromocriptine due to side effects or poor prolactin response and one was switched from cabergoline to bromocriptine as she was planning pregnancy. Median dose of bromocriptine was $10 \mathrm{mg} /$ day (range $5-20 \mathrm{mg} /$ day) and median dose of cabergoline $2 \mathrm{mg} /$ week (range $0.5-4.5 \mathrm{mg} /$ week). Three patients underwent surgery: two by transsphenoidal approach and one had a craniotomy. The indications for surgery were visual field deficits in two patients (one persisting despite DAs and the other presented with acute pituitary apoplexy) and exploration of a lesion suspicious for pituitary adenoma in another patient (this patient presented in 1988 when only lower resolution computed tomography (CT) scanning was available).

\section{Cushing's disease $(\mathbf{n}=5)$}

Five patients had Cushing's disease (CD) (four microadenomas; Table 3). Mean age at diagnosis was 13.8 years (median 15). All reported significant weight gain and recent slow growth. All underwent transsphenoidal surgery (TSS), following which clinical and biochemical remission were achieved. Two patients relapsed (one 24 months and another 88 months post surgery) and required repeat surgery and one received fractionated conventional radiotherapy after undergoing a 3rd TSS

Table 2 Clinical features at presentation in patients with a diagnosis of prolactinoma.

\begin{tabular}{|c|c|c|c|c|c|c|c|c|c|c|}
\hline Case & Sex & $\begin{array}{l}\text { Age } \\
\text { diag }\end{array}$ & $\begin{array}{l}\text { Age } \\
\text { now }\end{array}$ & Type & $\begin{array}{l}\text { Initial } \\
\text { prolactin } \\
(\mathrm{mU} / \mathrm{l})\end{array}$ & $\begin{array}{l}\text { Latest } \\
\text { prolactin } \\
(\mathrm{mU} / \mathrm{l})\end{array}$ & Amenorrhoea & Galactorrhoea & Headache & $\begin{array}{l}\text { Visual } \\
\text { fields } \\
\text { affected }\end{array}$ \\
\hline 1 & $\mathrm{~F}$ & 19 & 45 & Mic & 4000 & 9 & $\mathrm{Sec}$ & Yes & - & - \\
\hline 2 & $\mathrm{~F}$ & 17 & 17 & Mac & 10200 & 390 & Prim & - & Yes & Yes \\
\hline 3 & $\mathrm{~F}$ & 15 & 23 & Mic & 1600 & 655 & Prim & - & - & - \\
\hline 4 & $\mathrm{~F}$ & 16 & 18 & Mac & 8491 & 492 & $\mathrm{Sec}$ & Yes & - & - \\
\hline 8 & $\mathrm{~F}$ & 17 & 35 & Mac & 2000 & 381 & $\mathrm{Sec}$ & Yes & - & - \\
\hline 9 & $\mathrm{~F}$ & 21 & 41 & Mic & Unk & 272 & $\mathrm{Sec}$ & - & - & - \\
\hline 10 & $\mathrm{~F}$ & 16 & 27 & Mac & 5055 & 737 & $\mathrm{Sec}$ & - & - & - \\
\hline 11 & $\mathrm{~F}$ & 17 & 24 & Mac & 18000 & 130 & Prim & Yes & - & - \\
\hline 12 & $\mathrm{~F}$ & 14 & 26 & Mac & 60000 & 5527 & - & - & Yes & Yes \\
\hline 13 & $\mathrm{~F}$ & 20 & 34 & Mic & 5780 & 375 & - & Yes & - & - \\
\hline 14 & $\mathrm{~F}$ & 18 & 25 & Mic & 1400 & 500 & Olig & Yes & - & - \\
\hline 17 & $M$ & 21 & 41 & Mac & 70000 & 11 & - & - & Yes & Yes \\
\hline 18 & $\mathrm{~F}$ & 21 & 30 & Mac & 6789 & 2781 & $\mathrm{Sec}$ & - & - & - \\
\hline 19 & $\mathrm{~F}$ & 20 & 34 & Mic & 1207 & 1232 & $\mathrm{Sec}$ & Yes & - & - \\
\hline 21 & $\mathrm{~F}$ & 16 & 18 & Mac & 4656 & 1809 & $\mathrm{Sec}$ & - & - & - \\
\hline 22 & $\mathrm{~F}$ & 18 & 34 & Mac & 6630 & 1367 & $\mathrm{Sec}$ & - & - & - \\
\hline 23 & $\mathrm{~F}$ & 20 & 24 & Mic & 1666 & 120 & Olig & Yes & - & - \\
\hline 24 & $\mathrm{~F}$ & 16 & 27 & Mic & Unk & 444 & Prim & - & Yes & - \\
\hline 25 & $\mathrm{~F}$ & 20 & 44 & Mic & 4000 & 711 & $\mathrm{Sec}$ & - & - & - \\
\hline 26 & $\mathrm{~F}$ & 16 & 37 & Mac & 4440 & 105 & $\mathrm{Sec}$ & - & Yes & - \\
\hline 27 & $\mathrm{~F}$ & 19 & 45 & Mic & 10000 & 510 & $\mathrm{Sec}$ & Yes & - & - \\
\hline 29 & $\mathrm{~F}$ & 19 & 36 & Mac & 2547 & 237 & $\mathrm{Sec}$ & - & - & - \\
\hline 30 & $\mathrm{~F}$ & 18 & 28 & Mac & 2037 & 409 & $\mathrm{Sec}$ & Yes & - & - \\
\hline 31 & $\mathrm{~F}$ & 18 & 27 & Mac & 24000 & 2 & Prim & - & - & - \\
\hline 33 & $\mathrm{~F}$ & 21 & 30 & Mic & 2500 & 275 & $\mathrm{Sec}$ & - & - & - \\
\hline 35 & $\mathrm{~F}$ & 14 & 16 & Mic & 1276 & 992 & $\mathrm{Sec}$ & Yes & - & - \\
\hline 39 & $\mathrm{~F}$ & 16 & 16 & Mac & 20100 & 10766 & Prim & Yes & - & - \\
\hline 40 & $\mathrm{~F}$ & 16 & 18 & Mic & 1661 & 120 & - & Yes & - & - \\
\hline 41 & $\mathrm{~F}$ & 20 & 20 & Mic & 3500 & N/A & Olig & - & - & - \\
\hline
\end{tabular}

Age diag, age at diagnosis; F, female; M, male; mic, microprolactinoma; mac, macroprolactinoma; amenorrhoea: prim, primary amenorrhoea; sec, secondary amenorrhoea; olig, oligomenorrhoea; N/A, not available; -, not present. 
Table 3 Demographic and clinical characteristics of patients diagnosed with Cushing's disease.

\begin{tabular}{|c|c|c|c|c|c|c|c|}
\hline $\begin{array}{l}\text { Case } \\
\text { number }\end{array}$ & Sex & $\begin{array}{l}\text { Age at } \\
\text { diagnosis } \\
\text { (years) }\end{array}$ & $\begin{array}{l}\text { Symptoms at } \\
\text { presentation }\end{array}$ & $\begin{array}{l}\text { Duration of } \\
\text { symptoms }\end{array}$ & $\begin{array}{l}\text { Clinical } \\
\text { findings }\end{array}$ & $\begin{array}{l}\text { BMI SDS } \\
\text { at diagnosis }\end{array}$ & $\begin{array}{l}\text { Current } \\
\text { age (years) }\end{array}$ \\
\hline 16 & M & 15.8 & $\begin{array}{l}\text { Headache, } \\
\text { weight gain }\end{array}$ & 3 years & $\begin{array}{l}\text { Cushingoid, mild hirsuitism, } \\
\text { striae hypertension }\end{array}$ & 2.8 & 18 \\
\hline 20 & M & 15 & Weight gain & $<1$ year & $\mathrm{N} / \mathrm{A}$ & $\mathrm{N} / \mathrm{A}$ & 26 \\
\hline 32 & M & 11 & $\begin{array}{l}\text { Headache, } \\
\text { weight gain }\end{array}$ & 8 months & Cushingoid & 2.4 & 29 \\
\hline 34 & $\mathrm{~F}$ & 15 & $\begin{array}{l}\text { Secondary } \\
\text { amenorrhoea, } \\
\text { weight gain }\end{array}$ & 1 year & $\begin{array}{l}\text { Cushingoid, hyperpigmented } \\
\text { striae, bruising }\end{array}$ & 1.9 & 28 \\
\hline 37 & M & 13.2 & $\begin{array}{c}\text { Weight gain, } \\
\text { headache }\end{array}$ & $<1$ year & Hypertension & 2.12 & 15 \\
\hline
\end{tabular}

M, male; F, female; N/A, details not available; BMI, body mass index.

for relapse 3 years later. The four patients still under follow-up are now in remission; the 5th has moved away and care has been transferred to another centre.

\section{Other pituitary adenomas $(\mathbf{n}=7)$}

One male patient (aged 20) with acromegaly presented with apoplexy (visual field deficits and seizures). Tall stature was noted, but baseline GH levels were not available. He was treated with craniotomy and conventional fractionated radiotherapy and $\mathrm{GH}$ is now within the normal range $(0.7 \mu \mathrm{g} / \mathrm{l})$, with insulin-like growth factor $1-16 \mathrm{ng} / \mathrm{ml}$. Six patients with non-functioning pituitary adenomas (NFPAs; three with macroadenoma) presented with varying symptoms (Table 1). Two of the macroadenoma patients presented with visual field deficits and the third macroadenoma patient was not in anatomical proximity to the optic chiasm.

\section{Current endocrine and metabolic status of entire cohort $(n=41)$}

Hormone replacement of the 41 patients, 10 currently received pituitary hormone replacement (Table 4). Five had anterior panhypopituitarism (GH, thyroxine, cortisol and gonadotrophin deficiency).
Only one patient with $\mathrm{CD}$ had central diabetes insipidus. None of the 14 patients with microprolactinoma received any hormone replacement, other than one patient who required oestrogen.

Thirteen patients were diagnosed with severe GHD during the entire period of follow-up. Four were diagnosed in childhood. Two of these currently received $\mathrm{GH}$ replacement (GHR) to help achieve maximal growth potential; another one was growing well, along the 50th centile for height and declined GHR. The fourth patient is now an adult and fulfils the United Kingdom National Institute for Health and Clinical Excellence (NICE) criteria, including Quality of Life-Assessment of GHD in adults, to continue GH in adulthood. Nine patients were diagnosed with severe GHD in adulthood and two of these were currently receiving GHR.

Of the 28 female patients with prolactinoma, 3 had conceived spontaneously ( 2 had two children each and 1 had a single child) and 3 required treatment for infertility (one successful pregnancy with clomiphene, another successful pregnancy where treatment is unknown and one awaiting fertility treatment). There have been no documented pregnancies in the five female patients in the cohort with non-prolactin-secreting adenomas; however, it is unknown how many are currently attempting pregnancy.

Table 4 Pituitary adenoma treatment and current pituitary hormone replacements of the entire cohort.

\begin{tabular}{|c|c|c|c|c|c|}
\hline & $\begin{array}{c}\text { Total } \\
(n=41)\end{array}$ & $\begin{array}{l}\text { Prolactinoma } \\
\quad(n=29)\end{array}$ & $\begin{array}{c}\text { ACTH-secreting } \\
\text { adenomas }(n=5)\end{array}$ & $\begin{array}{c}\text { GH-secreting } \\
\text { adenomas }(n=1)\end{array}$ & NFPA $(n=6)$ \\
\hline \multicolumn{6}{|l|}{ Treatment } \\
\hline Dopamine agonists & 30 & 29 & 0 & 0 & 1 \\
\hline Surgery - TS̆S & 9 & 2 & 5 & 0 & 2 \\
\hline Surgery - craniotomy & 4 & 1 & 0 & 1 & 2 \\
\hline Radiotherapy & 4 & 1 & 1 & 1 & 1 \\
\hline \multicolumn{6}{|c|}{ Current hormone replacement } \\
\hline Hydrocortisone & 9 & 4 & 2 & 1 & 2 \\
\hline Thyroxine & 5 & 1 & 1 & 1 & 2 \\
\hline Sex-steroid replacement & 7 & 3 & 1 & 1 & 2 \\
\hline GH & 5 & 2 & 2 & 0 & 1 \\
\hline Desmopressin & 1 & 0 & 1 & 0 & 0 \\
\hline
\end{tabular}

TSS, transsphenoidal surgery; NFPA, non-functioning pituitary adenoma. 
Table 5 Body mass index (BMI) of the cohort.

\begin{tabular}{clll}
\hline & At diagnosis & At latest follow-up & $\boldsymbol{P}$ value \\
\hline BMI $\left(\mathrm{kg} / \mathrm{m}^{2}\right)$ of entire cohort (excluding those with Cushing's & Mean 26.9 & Mean 30.2 \\
disease and two patients diagnosed $<2$ years ago) & Median 25 & Median 30.7 \\
& Range 17.2-41.3 & Range 17.4-46.7 \\
BMI SDS of entire cohort (excluding those with Cushing's & Mean 1.3 & Mean 1.9 \\
disease and two patients diagnosed $<2$ years ago) & Median 1.2 & Median 2.2 \\
BMI $\left(\mathrm{kg} / \mathrm{m}^{2}\right)$ of patients with Cushing's disease & Range -1.6 to 3.7 & Range -1.5 to 4.6 \\
& Mean 27.6 & Mean 24.5 \\
& Median 26.6 & Median 24.4 \\
BMI $\left(\mathrm{kg} / \mathrm{m}^{2}\right)$ of patients with prolactinoma & Range 24.4-32.6 & Range 21.9-29.5 \\
& Mean 27.9 & Mean 30.9 \\
& Median 28.1 & Median 31 \\
& Range 17.2-41.3 & Range 17.4-46.7 \\
\hline
\end{tabular}

Auxology and obesity Mean BMI and mean BMI SDS of the entire cohort increased from diagnosis to latest follow-up, excluding those with CD whose mean BMI decreased (Table 5). Thirteen patients had significant weight gain (increase in BMI $>2 \mathrm{~kg} / \mathrm{m}^{2}$ ) since diagnosis. Sixteen patients are now clinically obese $\left(\right.$ BMI $\left.>30 \mathrm{~kg} / \mathrm{m}^{2}\right), 11$ with BMI $30-35 \mathrm{~kg} / \mathrm{m}^{2}, 2$ with $35-40 \mathrm{~kg} / \mathrm{m}^{2}$ and 3 have morbid obesity with $\mathrm{BMI} \geq 40 \mathrm{~kg} / \mathrm{m}^{2}$. Five patients are currently being treated with the weight-loss medication orlistat and one patient has been referred to a hospital-based multidisciplinary weight management service.

Other cardiovascular risk factors Two patients currently received antihypertensive medications and two had type 2 diabetes. Twenty-six patients have had their serum lipid profile measured. Mean cholesterol was 5.6 (range 3.2-9.5) $\mathrm{mmol} / \mathrm{l}$, mean high-density lipoprotein cholesterol $1.3 \mathrm{mmol} / \mathrm{l}$ and mean low-density lipoprotein cholesterol $3.2 \mathrm{mmol} / \mathrm{l}$. Four patients have been treated for dyslipidaemia (mean cholesterol before treatment 9.2 (median 7.7) $\mathrm{mmol} / \mathrm{l}$ and mean treated cholesterol 5.7 (median 5.5) $\mathrm{mmol} / \mathrm{l}$ ). According to a recent health survey for England (21), mean total cholesterol for the 16-24 years of age group was $4.5 \mathrm{mmol} / \mathrm{l}$ (males) and $4.6 \mathrm{mmol} / \mathrm{l}$ (females). Mean total cholesterol in patients with severe GHD currently receiving GHR is $5.9 \mathrm{mmol} / \mathrm{l}$, in untreated patients $5.7 \mathrm{mmol} / \mathrm{l}$ and in $\mathrm{GH}$ sufficient patients 5.5 (range 4-8) $\mathrm{mmol} / \mathrm{l}$.

\section{Discussion}

Pituitary adenomas diagnosed in patients aged 21 years or younger are frequently hormonally active, accounting for 35/41 (85\%) patients in our study, in keeping with other studies that report $80-97 \%(3,4,6,7,10)$. Patients typically present with endocrine symptoms in keeping with their adenoma type and visual field deficits were present in only $15 \%$ of patients in our study. Detection of visual field deficits may also be dependent on method used for assessment of visual fields therefore it may be difficult to generalise this finding. Other studies on adolescents who had undergone surgery $(2,7)$ reported higher rates of visual symptoms at presentation $(2,7)$, however, they did not describe the tools used for assessment of visual fields, thereby making comparison less straightforward. Disruption of menses was the commonest symptom in our series, seen in $85 \%$ of female patients, the majority of whom had a prolactinoma. Other studies $(2,6,9)$ reported amenorrhoea in $75-100 \%$ of patients with prolactinomas. Galactorrhoea was the second commonest presenting symptom in our patients. Weight gain occurred in all patients diagnosed with CD, but also in 6/29 (21\%) patients with prolactinoma and $2 / 6(33 \%)$ patients with NFPA. Short and tall statures were rare in our study similar to other studies $(6,9-11)$.

In common with other studies $(6,7)$, prolactinoma was the commonest pituitary adenoma seen in our group $(71 \%)$, with all except one being female. All but two of our patients were treated with DA as first-line therapy. This is in contrast with other prolactinoma studies $(6,9,11)$. Cannavo et al. (6) described a series of 18 macroprolactinomas, half of which underwent surgery; only 8 patients with macroprolactinomas were successfully treated with DA as first line (6). Five out of 12 patients with a microprolactinoma from the same study underwent surgery, the indication for which was not stated (6). Colao et al. (9) described 26 patients with prolactinomas, 9 of which underwent surgery before a trial of DA for 'symptoms of tumour expansion' (9), before assessment by an endocrinologist (only 2 were noted to have visual field defects, and 7 had microprolactinoma). After initiation of DA treatment, all 26 patients had normalisation of prolactin within 6-12 months and significant shrinkage in tumour size was seen in 10 patients. The effectiveness of DAs was noted and the possibility that surgery could have been avoided in those nine cases was suggested. All patients remained on DA therapy at publication of the series.

Kunwar \& Wilson (11) described that all 78 of their patients with prolactinoma underwent TSS, as surgical management as their first-line treatment. Their reason for this was good outcome (although this was not defined), 
with long-term surgical cure of $82 \%$ as reported in Mindermann's series (10) compared with a need for lifelong DA treatment. They make no mention of subsequent hormone sufficiency/deficiencies or relapse/cure rates in their patients. Our own experience is that DA therapy has been successfully stopped in nine of our patients (seven microprolactinomas and two macroprolactinomas), with no evidence of recurrence (median follow-up after stopping DAs 4 years, range 1-10 years). Based on our experience and given the clinical effectiveness of DAs, the frequency of recurrence of hyperprolactinaemia following surgery (22) and the infrequency of visual problems at presentation, as shown in our series, children and adolescents with both macro- and microprolactinomas, should receive DAs as first-line treatment, as is recommended in adults (22).

CD accounted for $12 \%$ of cases in our study and presented with the characteristic stigmata. TSS for removal of ACTH-secreting adenomas can be technically challenging in children and the failure rate even in the most experienced hands can be significant. Cure rates reported from paediatric studies vary between 45 and $97 \%(14,23-28)$. Lifelong follow-up is mandatory, due to the possibility of recurrence after initial cure.

Weight gain and obesity occurring as a result of pituitary tumours or their treatment may lead to significant morbidity and mortality. Interestingly, the five patients in our study with the highest BMI at diagnosis (range $33.8-41.3 \mathrm{~kg} / \mathrm{m}^{2}$ ) had prolactinomas; three had lost weight following treatment, however, two had gained significant weight (BMI increased from 35 to 41.2 and 33.8 to $39.5 \mathrm{~kg} / \mathrm{m}^{2}$ ), despite normalisation of prolactin to well within the normal range (prolactin 130 and $11 \mathrm{mU} / \mathrm{l}$ respectively). Weight gain in adult patients with prolactinomas and weight loss after treatment remain controversial, with some studies reporting weight loss following normalisation of prolactin (29), whereas others suggest no effect (30).

Atherosclerosis (and therefore cardiovascular damage) often begins in childhood and progresses with age (31), with dyslipidaemia in overweight and obese adolescents shown to be associated with higher carotid intima-media thickness (a surrogate marker of atherosclerosis) in adulthood (32). Adachi et al. (33) found that $39 \%$ of children and adolescents with suprasellar tumours were hyperlipidaemic, increasing to $58 \%$ in those with a BMI $>90$ th percentile. The same study also found an increased risk of vascular events associated with an unfavourable atherogenic lipoprotein profile.

In the UK, NICE currently recommends that clinicians should consider measuring lipids when investigating co-morbidities in children with BMI $\geq 98$ th centile for age. As both obesity and hyperlipidaemia are important modifiable risk factors for cardiovascular disease, we feel that early identification and weight loss interventions with the aim to reduce both of these factors are extremely important in this patient group and suggest routine measurement of lipids in patients with adenomas.

Pituitary adenomas are familial in about $5 \%$ of cases (34) and are known to be associated with MEN-1 syndrome (present in two patients in our series) and also Carney complex; however, recently mutations in the aryl-hydrocarbon receptor interacting protein gene have been identified in some cases of familial isolated pituitary adenoma and, significantly to this series, these mutations have been associated with a lower age of onset of pituitary disease and with larger and more invasive/aggressive tumours (35-41). Therefore, routine questioning about family history of pituitary disorders is important in this age group.

In conclusion, this is one of the largest reviews of patients aged 21 or younger at diagnosis of pituitary tumour, seen in a joint neuroendocrine setting, followed up by a single service. Hormonally active tumours are more common than NFPAs, with two-thirds of cases diagnosed as prolactinoma. Treatment with DA is safe and effective, and should be the first-line treatment for prolactinomas. Surgery is required as first-line treatment only in CD and acromegaly or in NFPAs with threat to vision. Increased cardiovascular risk factors (obesity and dyslipidaemia) and infertility are important sequelae and their active identification and treatment are necessary. Genetic association should be considered by taking a careful family history.

\section{Declaration of interest}

The authors declare that there is no conflict of interest that could be perceived as prejudicing the impartiality of the research reported.

\section{Funding}

This research did not receive any specific grant from any funding agency in the public, commercial or not-for-profit sector.

\section{Acknowledgements}

Eli Lilly and Co. for an unrestricted educational grant and the Audit Department at the Walton Centre for Neurology and Neurosurgery in Liverpool, UK.

\section{References}

1 Lafferty AR \& Chrousos GP. Pituitary tumors in children and adolescents. Journal of Clinical Endocrinology and Metabolism 1999 84 4317-4323. (doi:10.1210/jc.84.12.4317)

2 Webb C \& Prayson RA. Pediatric pituitary adenomas. Archives of Pathology and Laboratory Medicine 2008132 77-80.

3 Mehrazin M. Pituitary tumors in children: clinical analysis of 21 cases. Child's Nervous System 200723 391-398. (doi:10.1007/ s00381-006-0259-4)

4 Mukai K, Seljeskog EL \& Dehner LP. Pituitary adenomas in patients under 20 years old. A clinicopathological study of 12 cases. Journal of Neuro-Oncology 19864 79-89. (doi:10.1007/BF0 2158007) 
5 Lee AG, Sforza PD, Fard AK, Repka MX, Baskin DS \& Dauser RC. Pituitary adenoma in children. Journal of Neuro-Ophthalmology 199818 102-105.

6 Cannavo S, Venturino M, Curto L, De Menis E, D'Arrigo C, Tita P, Billeci D \& Trimarchi F. Clinical presentation and outcome of pituitary adenomas in teenagers. Clinical Endocrinology $2003 \mathbf{5 8}$ 519-527. (doi:10.1046/j.1365-2265.2003.01748.x)

7 Pandey P, Ojha BK \& Mahapatra AK. Pediatric pituitary adenoma: a series of 42 patients. Journal of Clinical Neuroscience 200512 124-127. (doi:10.1016/j.jocn.2004.10.003)

8 Tamura T, Tanaka R, Korii K \& Okazaki H. Pediatric pituitary adenoma. Endocrine Journal 200047 S95-S99. (doi:10.1507/ endocrj.47.SupplMarch_S95)

9 Colao A, Loche S, Cappa M, Di Sarno A, Landi ML, Sarnacchiaro F, Facciolli G \& Lombardi G. Prolactinomas in children and adolescents. clinical presentation and long-term follow-up. Journal of Clinical Endocrinology and Metabolism $1998 \mathbf{8 3}$ 2777-2780. (doi:10.1210/jc.83.8.2777)

10 Mindermann T \& Wilson CB. Pediatric pituitary adenomas. Neurosurgery 199536 259-269. (doi:10.1227/00006123199502000-00004)

11 Kunwar S \& Wilson CB. Pediatric pituitary adenomas. Journal of Clinical Endocrinology and Metabolism $1999 \quad \mathbf{8 4} 4385-4389$. (doi:10.1210/jc.84.12.4385)

12 Mindermann T \& Wilson CB. Age-related and gender-related occurrence of pituitary adenomas. Clinical Endocrinology $1994 \mathbf{4 1}$ 359-364. (doi:10.1111/j.1365-2265.1994.tb02557.x)

13 Abe T, Ludecke DK \& Saeger W. Clinically nonsecreting pituitary adenomas in childhood and adolescence. Neurosurgery $1998 \mathbf{4 2}$ 744-750. (doi:10.1097/00006123-199804000-00037)

14 Dyer EH, Civit T, Visot A, Delalande O \& Derome P. Transsphenoidal surgery for pituitary adenomas in children. Neurosurgery 199434 207-212. (doi:10.1227/00006123-199402000-00001)

15 Hirshfeld-Cytron J \& Kim HH. Treatment of infertility in women with pituitary tumors. Expert Review of Anticancer Therapy 20066 (Supplement 9) S55-S62. (doi:10.1586/14737140.6.9s.S55)

16 Hall R, Manski-Nankervis J, Goni N, Davies MC \& Conway GS. Fertility outcomes in women with hypopituitarism. Clinical Endocrinology $2006 \mathbf{6 5}$ 71-74. (doi:10.1111/j.1365-2265. 2006.02550.x)

17 Green DM, Kawashima T, Stovall M, Leisenring W, Sklar CA, Mertens AC, Donaldson SS, Byrne J \& Robison LL. Fertility of female survivors of childhood cancer: a report from the childhood cancer survivor study. Journal of Clinical Oncology 200927 2677-2685. (doi:10.1200/JCO.2008.20.1541)

18 Tomlinson JW, Holden N, Hills RK, Wheatley K, Clayton RN, Bates AS, Sheppard MC \& Stewart PM. Association between premature mortality and hypopituitarism. West Midlands prospective hypopituitary study group. Lancet 2001357 425-431. (doi:10.1016/S0140-6736(00)04006-X)

19 Deepak D, Furlong NJ, Wilding JP \& MacFarlane IA. Cardiovascular disease, hypertension, dyslipidaemia and obesity in patients with hypothalamic-pituitary disease. Postgraduate Medical Journal 200783 277-280. (doi:10.1136/pgmj.2006.052241)

20 Daousi C, Dunn AJ, Foy PM, MacFarlane IA \& Pinkney JH. Endocrine and neuroanatomic features associated with weight gain and obesity in adult patients with hypothalamic damage. American Journal of Medicine 2005118 45-50. (doi:10.1016/ j.amjmed.2004.06.035)

21 Health Survey for England. Available from: http://www.dh.gov. uk/en/Publicationsandstatistics/Publications/PublicationsStatistics/DH_4098712, 2003.

22 Casanueva FF, Molitch ME, Schlechte JA, Abs R, Bonert V, Bronstein MD, Brue T, Cappabianca P, Colao A, Fahlbusch R, Fideleff H, Hadani M, Kelly P, Kleinberg D, Laws E, Marek J, Scanlon M, Sobrinho LG, Wass JA \& Giustina A. Guidelines of the Pituitary Society for the diagnosis and management of prolactinomas. Clinical Endocrinology 200665 265-273. (doi:10.1111/ j.1365-2265.2006.02562.x)

23 Leinung MC, Kane LA, Scheithauer BW, Carpenter PC, Laws ER Jr \& Zimmerman D. Long term follow-up of transsphenoidal surgery for the treatment of Cushing's disease in childhood. Journal of Clinical Endocrinology and Metabolism $1995 \mathbf{8 0}$ 2475-2479. (doi:10.1210/jc.80.8.2475)

24 Linglart A \& Visot A. Cushing's disease in children and adolescents. Neuro-Chirurgie $2002 \mathbf{4 8} 271-280$.

25 Magiakou MA, Mastorakos G, Oldfield EH, Gomez MT, Doppman JL, Cutler GB Jr, Nieman LK \& Chrousos GP. Cushing's syndrome in children and adolescents. Presentation, diagnosis, and therapy. New England Journal of Medicine 1994331 629-636. (doi:10.1056/NEJM199409083311002)

26 Massoud AF, Powell M, Williams RA, Hindmarsh PC \& Brook CG. Transsphenoidal surgery for pituitary tumours. Archives of Disease in Childhood $1997 \mathbf{7 6}$ 398-404. (doi:10.1136/adc.76.5.398)

27 Styne DM, Grumbach MM, Kaplan SL, Wilson CB \& Conte FA. Treatment of Cushing's disease in childhood and adolescence by transsphenoidal microadenomectomy. New England Journal of Medicine 1984310 889-893. (doi:10.1056/NEJM1984040 53101405)

28 Partington MD, Davis DH, Laws ER Jr \& Scheithauer BW. Pituitary adenomas in childhood and adolescence. Results of transsphenoidal surgery. Journal of Neurosurgery 1994 80 209-216. (doi:10. 3171/jns.1994.80.2.0209)

29 Greenman Y, Tordjman K \& Stern N. Increased body weight associated with prolactin secreting pituitary adenomas: weight loss with normalization of prolactin levels. Clinical Endocrinology 199848 547-553. (doi:10.1046/j.1365-2265.1998.00403.x)

30 Soran H, Wilding J \& MacFarlane I. Body weight and prolactinoma: a retrospective study. International Journal of Obesity and Related Metabolic Disorders 200428 183. (doi:10.1038/sj.ijo. 0802492)

31 McCrindle BW, Urbina EM, Dennison BA, Jacobson MS, Steinberger J, Rocchini AP, Hayman LL, Daniels SR \& American Heart Association Atherosclerosis, Hypertension, and Obesity in Youth Committee, American Heart Association Council of Cardiovascular Disease in the Young \& American Heart Association Council on Cardiovascular Nursing. Drug therapy of high-risk lipid abnormalities in children and adolescents: a scientific statement from the American Heart Association Atherosclerosis, Hypertension, and Obesity in Youth Committee, Council of Cardiovascular Disease in the Young, with the Council on Cardiovascular Nursing. Circulation 2007115 1948-1967. (doi:10.1161/CIRCULATIONAHA.107.181946)

32 Magnussen CG, Venn A, Thomson R, Juonala M, Srinivasan SR, Viikari JS, Berenson GS, Dwyer T \& Raitakari OT. The association of pediatric low- and high-density lipoprotein cholesterol dyslipidemia classifications and change in dyslipidemia status with carotid intima-media thickness in adulthood evidence from the cardiovascular risk in young Finns study, the Bogalusa heart study, and the CDAH (childhood determinants of adult health) study. Journal of the American College of Cardiology 200953 860-869. (doi:10.1016/j.jacc.2008.09.061)

33 Adachi M, Muroya K \& Asakura Y. Unfavorable lipoprotein profile in childhood cancer survivors with suprasellar brain tumors - a high apo B level and increased small dense LDL-cholesterol. Child's Nervous System 200925 669-675. (doi:10.1007/s00381-0090837-3)

34 Daly AF, Tichomirowa MA \& Beckers A. Update on familial pituitary tumors: from multiple endocrine neoplasia type 1 to familial isolated pituitary adenoma. Hormone Research $2009 \mathbf{7 1}$ (Supplement 1) 105-111. (doi:10.1159/000178050)

35 Leontiou CA, Gueorguiev M, van der Spuy J, Quinton R, Lolli F, Hassan S, Chahal HS, Igreja SC, Jordan S, Rowe J, Stolbrink M, Christian HC, Wray J, Bishop-Bailey D, Berney DM, Wass JA, Popovic V, Ribeiro-Oliveira AJr Jr, Gadelha MR, Monson JP, Akker SA, Davis JR, Clayton RN, Yoshimoto K, Iwata T, Matsuno A, Eguchi K, Musat M, Flanagan D, Peters G, Bolger GB, Chapple JP, Frohman LA, Grossman AB \& Korbonits M. The role of the aryl hydrocarbon receptor-interacting protein gene in familial and sporadic pituitary adenomas. Journal of Clinical Endocrinology and Metabolism 200893 2390-2401. (doi:10.1210/jc.2007-2611) 
36 Naves LA, Daly AF, Vanbellinghen JF, Casulari LA, Spilioti C, Magalhaes AV, Azevedo MF, Giacomini LA, Nascimento PP, Nunes RO, Rosa JW, Jaffrain-Rea ML, Bours V \& Beckers A. Variable pathological and clinical features of a large Brazilian family harboring a mutation in the aryl hydrocarbon receptorinteracting protein gene. European Journal of Endocrinology 2007 157 383-391. (doi:10.1530/EJE-07-0533)

37 Vierimaa O, Georgitsi M, Lehtonen R, Vahteristo P, Kokko A, Raitila A, Tuppurainen K, Ebeling TM, Salmela PI, Paschke R, Gundogdu S, De Menis E, Makinen MJ, Launonen V, Karhu A \& Aaltonen LA. Pituitary adenoma predisposition caused by germline mutations in the AIP gene. Science 2006312 1228-1230. (doi:10.1126/science.1126100)

38 Toledo RA, Lourenco DM Jr, Liberman B, Cunha-Neto MB, Cavalcanti MG, Moyses CB, Toledo SP \& Dahia PL. Germline mutation in the aryl hydrocarbon receptor interacting protein gene in familial somatotropinoma. Journal of Clinical Endocrinology and Metabolism 200792 1934-1937. (doi:10.1210/jc.2006-2394)

39 Cazabat L, Libe R, Perlemoine K, Rene-Corail F, Burnichon N, Gimenez-Roqueplo AP, Dupasquier-Fediaevsky L, Bertagna X, Clauser E, Chanson P, Bertherat J \& Raffin-Sanson ML. Germline inactivating mutations of the aryl hydrocarbon receptor-interacting protein gene in a large cohort of sporadic acromegaly: mutations are found in a subset of young patients with macroadenomas. European Journal of Endocrinology $2007 \mathbf{1 5 7}$ 1-8. (doi:10.1530/EJE-07-0181)

40 Georgitsi M, De Menis E, Cannavò S, Mäkinen MJ, Tuppurainen K, Pauletto P, Curtò L, Weil RJ, Paschke R, Zielinski G, Wasik A, Lubinski J, Vahteristo P, Karhu A \& Aaltonen LA. Aryl hydrocarbon receptor interacting protein (AIP) gene mutation analysis in children and adolescents with sporadic pituitary adenomas. Clinical Endocrinology 200869 621-627. (doi:10. $1111 /$ j.1365-2265.2008.03266.x)

41 Daly AF, Tichomirowa MA \& Beckers A. The epidemiology and genetics of pituitary adenomas. Best Practice and Research. Clinical Endocrinology and Metabolism 200923 543-554. (doi:10.1016/ j.beem.2009.05.008)

Received 3 August 2010

Accepted 4 August 2010 